\title{
Pengukuran Kinerja Dengan Pendekatan Balanced Scorecard Pada Perusahaan Ekspedisi PT. CY
}

\author{
M. Pradipto
}

\begin{abstract}
Abstrak-Penelitian dalam artikelini membahas tentang pengukuran kinerja pada suatu perusahaan ekspedisi PT. CY. Pengukuran kinerja yang dilakukan adalah pengukuran perusahaan pada saat ini dan pengukuran kinerja dengan Balanced Scorecard. Adapun tujuan penelitian ini adalah untuk mengidentifikasi sistem pengukuran kinerja yang dilakukan perusahaan pada saat ini, melakukan pengukuran kinerja dengan menggunakan Balanced Scorecard dan melakukan perbaikan dengan pembuatanpeta strategi dan tabel key performance indicators (KPI). Proses pembobotan perspektif dan indikator-indikator utama penyusun tabel KPI menggunakan metode Analytic Hierarchy Process (AHP). Hasil penelitian pada artikelini menunjukkan bahwa metode pengukuran kinerjayang dilakukan perusahaan pada saat ini sangat tidak memadai dan metode Balanced Scorecard menjadi sistem pengukuran yang tepat dan dibutuhkan PT. CY saat ini. Hasil perhitungan tabel KPI pada penelitian ini menunjukkan betapa buruknya kinerja perusahaan secara keseluruhan. Aspek yang menjadi prioritas utama karena memiliki bobot terbesar sebagai penentu peningkatan kinerja PT. CY adalah aspek finansial 43,10\%, kemudian aspek pembelajaran dan pertumbuhan 37,37\%, kemudian aspek proses bisnis internal 14,47\%, dan yang terakhir adalah aspek pelanggan $4,76 \%$.
\end{abstract}

Kata Kunci-Analytic Hierarchy Process, Balanced Scorecard, Key Performance Indicators, Peta Strategi

Abstract - The research in this article discusses performance measurement in an expedition company PT. CY. Performance measurements performed are current company measurements and performance measurements with the Balanced Scorecard. The purpose of this study is to identify the company's performance measurement system at this time, to measure performance using the Balanced Scorecard and make improvements by making strategy maps and key performance indicators (KPI) tables. The process of weighting perspective and key indicators compiling the KPI table uses the Analytic Hierarchy Process (AHP) method. The results of this study indicate that the company's current performance measurement methods are inadequate and the Balanced Scorecard method is the right measurement system needed by PT. CY at the moment. The KPI table calculation results in this study show how bad the company's overall performance is. The aspect that becomes the main priority because it has the biggest weight as a determinant of the performance improvement of PT. CY is $43.10 \%$ financial aspects, then $37.37 \%$ learning and growth aspects, then $14.47 \%$ internal business process aspects, and the last is $4.76 \%$ customer aspects.

Keywords-Analytic Hierarchy Process, Balanced Scorecard, Key Performance Indicators, Strategy Map

\section{PENDAHULUAN}

Saat ini industri ekspedisi demikian padat dan $N_{\text {persaingannya begitu ketat. Banyak perusahaan }}$ yang bermain di bidang ekspedisi berlomba-lomba untuk memberikan pelayanan terbaik demi mendapatkan kepuasan dan kesetiaan pelanggan, Menjadi sebuah perusahaan ekspedisi yang kompetitif haruslah memiliki kinerja perusahaan yang baik dan tangguh.

PT. CY adalah perusahaan yang bergerak dalam pelayanan jasa ekspedisi dan logistik, yakni jasa pengiriman dokumen dan barang/paket, baik antar kota (inter city) maupun dalam kota (intra city) di seluruh wilayah Indonesia. Namun, berdasarkan data pendapatan perusahaan (revenue) yang dikumpulkan oleh Departemen Accounting untuk jangka waktu

Masri Pradipto, Dosen Teknik Industri, Universitas Indraprasta PGRI, Jakarta. (masri.pradipto@unindra.ac.id).
2009-2013, hasilnya seperti yang ditunjukkan Tabel I. Penghasilan PT. CY cenderung mengalami penurunan. Tentu ini adalah fenomena yang sangat disayangkan dan merupakan gambaran kasar atas kinerja PT. CY yang buruk. Hal ini bisa berarti bahwa ada sejumlah pelanggan yang akhirnya memutuskan untuk tidak menggunakan jasa PT. CY lagi dan tentu saja merugikan bagi PT. CY.

TABEL 1

DATA REVENUE PT. CY PER TAHUN (DALAM MILYAR)

\begin{tabular}{cccccc} 
Data & 2009 & 2010 & 2011 & 2012 & 2013 \\
Revenue & 82,171 & 82,908 & 63,297 & 64,629 & 51,414 \\
\hline
\end{tabular}

PT. CY selama menjalankan usahanya belum memiliki sebuah metode untuk menilai kinerja perusahaan serta perkembangannya dari tahun ke tahun. Pengukuran kinerja perusahaan masih dilakukan secara konservatif yakni hanya dengan menggunakan perspektif finansial dan sedikit 
perspektif dari sisi departemen lain. Tentu saja pengukuran dengan menggunakan perspektif ini tidak bisa memotret kondisi perusahaan secara keseluruhan, baik secara internal apalagi eksternal. Fenomena ini sesuai dengan fenomena dalam [1], banyak perusahaan kecil di Inggris dan Siprus yang tidak menggunakan Balanced Scorecard dan hanya mengandalkan laporan keuangan untuk pengambilan keputusan, hal ini disebabkan karena masih kurangnya pengetahuan dan kesadaran tentang penggunaan Balanced Scorecard.

Artikel [1] menjelaskan bahwa Balanced Scorecard adalah penilaian kinerja dan sistem manajemen strategis yang cocok digunakan oleh semua jenis dan skala usaha. Kekuatan terbesar Balanced Scorecard adalah kemampuannya dalam mengintegrasikan pengukuran keuangan dan nonkeuangan bersama-sama dengan cara mengukur kinerja strategis dan usaha melalui empat perspektif yang saling berkaitan.

Sejak diperkenalkan sejak era tahun 1990-an oleh Robert S. Kaplan dan David P. Norton. Dalam [2] dijelaskan keunggulan dari alat ini adalah tidak hanya menggunakan perspektif keuangan (financial) saja namun juga menggunakan perspektif-perspektif yang lain yakni perspektif pelanggan (customer), perspektif bisnis internal (internal business) perspektif pembelajaran dan pertumbuhan (learning and growth). Penting untuk menerapkan Balanced Scorecard karena metode ini memiliki kegunaan diantaranya :

1. Meningkatkan fokus pada strategi dan hasil

2. Meningkatkan kinerja organisasi dengan mengukur apa yang penting

3. Pemerataan strategi organisasi kepada orang-orang yang melakukan pekerjaan dari hari ke hari

4. Fokus pada faktor pendorong kinerja masa depan

5. Meningkatkan komunikasi organisasi visi dan strategi

Penelitian [3] sebagai penelitian terdahulu fokusnya adalah melakukan perancangan sistem pengukuran kinerja dengan menggunakan alat Balanced Scorecard berbasis analisis SOAR (Strength, Opportunity, Aspiration dan Result) untuk menghasilkan key performance indicator (KPI) sebagai tolok ukur kinerja di PT. Jawa Pos Media Televisi. Setelah diperoleh KPI maka selanjutnya adalah melakukan pembobotan dengan meng-gunakan metode Analytic Hierarchy Process (AHP). Selain merancang sistem pengukuran kinerja untuk perusahaan, penelitian ini juga melakukan deployment sistem pengukuran kinerja perusahaan ke Divisi Pemberitaan.

Penelitian ini menggunakan cara yang kurang lebih sama dengan [3], yakni dalam hal penentuan indikator-indikator dari empat perspektif Balanced Scorecard.

Pengumpulan dan penentuan indikator-indikator pada penelitian ini dilakukan dengan melakukan wawancara dan brainstorming dengan para supervisor, manajer dan manajer senior yang merupakan representasi dari masing-masing departemen di PT. CY.

Bedanya dengan [3] adalah, pada penelitian ini tidak dilakukan deployment sistem pengukuran kinerja pe-rusahaan ke sebuah divisi /departemen tertentu. Jadi lebih ke pengukuran kinerja perusahaan secara global dengan pembuatan strategy map dan tabel KPI.

Penelitian [4] fokusnya adalah melakukan evaluasi terhadap sistem manajemen perusahaan Induk Koperasi Perikanan Indonesia, yang dimulai dari analisis visi, misi, dan strategi perusahaan dengan menggunakan analisis SWOT untuk internal perusahaan dan analisis Porter's Five-Forces Competitive Model untuk eksternal perusahaan. Hasil yang didapat dari penelitian ini adalah perancangan strategy map, perancangan Balanced Scorecard dan perancangan tabel KPI untuk perusahaan.

Penelitian pada karya tulis ini hampir mirip dengan [4]. Penelitian ini hanya menggunakan Porter's Five-Forces Competitive Model untuk mengetahui visi, misi, serta strategi perusahaan apakah masih relevan dengan kondisi saat ini atau tidak. Penelitian ini juga menghasilkan strategy map dan tabel KPI untuk perusahaan. Bedanya adalah, selain perancangan Balanced Scorecard, penelitian ini menggunaan tabel KPI yang telah dibuat dan mengisinya dengan kinerja perusahaan saat ini.

\section{METODE DAN PROSEDUR}

Tahapan penelitian pada artikel ini dibagi menjadi tiga tahap, yakni tahapan pra penelitian, penelitian dan pasca penelitian. Silahkan lihat Gambar 1.

Data yang dikumpulkan untuk mendukung penelitian ini dibagi menjadi dua bagian yaitu, pertama data untuk mengukur kinerja perusahaan dengan cara dipakai saat ini. Kedua, data untuk mengukur kinerja perusahaan dengan Balanced Scorecard.

Data dikumpulkan dengan beragam cara. Meminta langsung ke departemen terkait, mengambil dari sistem informasi logistik PT. CY bernama LOGINS, sampai dengan proses wawancara dan brainstorming dengan perwakilan departemen. Data yang diambil diantaranya data untuk penentuan sasaran strategis dari empat perspektif Balanced 
Scorecard dan indikator-indikator turunannya untuk kemudian diseleksi dan diolah lebih lanjut.

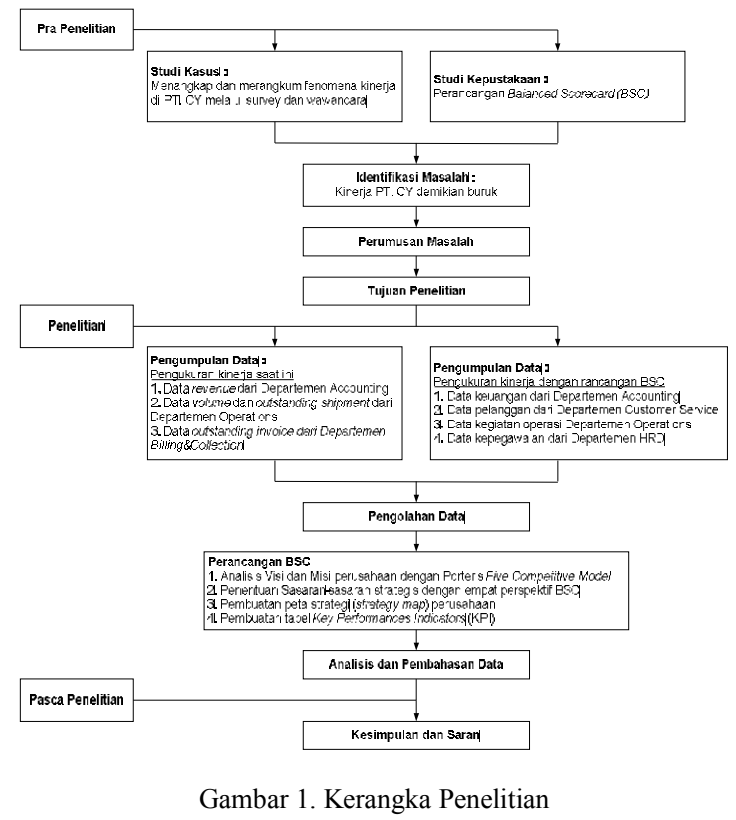

\section{A. Pengolahan Data Pengukuran Kinerja dengan Metode Saat Ini}

Berikut adalah data yang biasanya dipakai untuk mengukur kinerja perusahaan dengan metode saat ini:

1. Data revenue dari Departemen Accounting.

2. Data Shipment Volume dari Departemen Operations.

3. Data Outstanding Shipment dari Departemen Operations.

4. Data Outstanding Invoice dari Departemen Billing and Collection.

Semua data tersebut didapatkan langsung dengan cara mengunduhnya dari sistem LOGINS dengan sedikit pengolahan sederhana.

\section{B. Pengolahan Data Pengukuran Kinerja dengan Metode Balanced Scorecard}

Tahapan-tahapan pengolahan data yang dipakai dalam metode Balanced Scorecard yaitu:

1. Proses seleksi indikator-indikator dengan metode USG (Urgent, Seriousness, Growth).

2. Pembobotan indikator-indikator dengan metode AHP (Analytic Hierarchy Process).

3. Perhitungan Indikator-indikator Utama Tabel KPI.

Artikel [5] menjelaskan bahwa Urgency, Seriousness, Growth (USG) adalah salah satu alat untuk menyusun urutan prioritas isu yang harus diselesaikan, diperkenalkan oleh Kepner dan Tregoe (1981). Caranya dengan menentukan tingkat urgensi, keseriusan, dan perkembangan isu dengan menentukan skala nilai $1-5$ atau 1-10. Isu yang memiliki total skor tertinggi merupakan isu prioritas.

TABEL 2

PRIORITAS DENGAN METODE USG

\begin{tabular}{|c|c|c|c|c|}
\hline Masalah & Urgency & Seriousness & Growth & Total \\
\hline $\begin{array}{l}\text { Masalah } 1 \\
\text { Masalah } 2 \\
\text { Masalah } 3\end{array}$ & & & & \\
\hline
\end{tabular}

Skala prioritas yang digunakan :
1. Rendah Sekali
2. Rendah
3. Sedang
4. Tinggi
5. Tinggi Sekali

Analytic Hierarchy Process dalam [6] didefiniskan sebagai suatu model pengambil keputusan yang komprehensif dengan memperhitungkan hal-hal yang bersifat kualitatif dan kuantitatif. Model pengambilan keputusan dengan AHP pada dasarnya berusaha menutupi semua kekurangan dari model-model sebelumnya. Peralatan utama dari model ini adalah sebuah hierarki fungsional dengan input utamanya adalah persepsi manusia. Jadi perbedaan yang mencolok model AHP dengan model lainnya terletak pada jenis inputnya.

AHP lebih lanjut dijelaskan dalam [6] mampu menyediakan kerangka yang memungkinkan untuk membuat suatu keputusan efektif atas isu kompleks dengan menyederhanakan dan mempercepat proses pendukung keputusan. Pada dasarnya AHP adalah suatu metode dalam merinci suatu situasi yang kompleks, yang terstruktur ke dalam suatu komponen-komponennya. Artinya, dengan metode AHP kita dapat memecahkan suatu masalah dalam pengambilan keputusan.

Pada penelitian ini dilakukan sebanyak enam tahap proses pembobotan, yakni :

1. Pembobotan untuk empat perspektif Balanced Scorecard

2. Pembobotan indikator-indikator perspektif keuangan (financial)

3. Pembobotan indikator-indikator perspektif pelanggan (customer)

4. Pembobotan indikator-indikator perspektif proses bisnis internal (internal business process)

5. Pembobotan indikator-indikator perspektif pembelajaran dan pertumbuhan (learning and growth)

6. Pembobotan indikator-indikator utama KPI

Proses pembobotan dengan menggunakan metode AHP diawali dengan pembuatan tabel matriks perbandingan berpasangan (pairwise comparison matrix) terlebih dahulu. Tabel III menunjukkan contoh tabel matriks perbandingan berpasangan untuk empat kriteria.

TABEL 3

MATRIKS PERBANDINGAN BERPASANGAN

\begin{tabular}{ccccc} 
Kriteria & Kriteria 1 & Kriteria 2 & Kriteria 3 & Kriteria 4 \\
\hline Kriteria 1 & 1 & $\mathrm{~B} 1$ & $\mathrm{C} 1$ & $\mathrm{D} 1$ \\
Kriteria 2 & $1 / \mathrm{B} 1$ & 1 & $\mathrm{C} 2$ & $\mathrm{D} 2$ \\
Kriteria 3 & $1 / \mathrm{C} 1$ & $1 / \mathrm{C} 2$ & 1 & D3 \\
\hline
\end{tabular}




\begin{tabular}{ccccc}
\hline Kriteria 4 & $1 / \mathrm{D} 1$ & $1 / \mathrm{D} 2$ & $1 / \mathrm{D} 3$ & 1 \\
Jumlah & $\mathrm{A} 4$ & $\mathrm{~B} 4$ & $\mathrm{C} 4$ & $\mathrm{D} 4$ \\
\hline
\end{tabular}

Tabel matriks perbandingan tersebut diberikan skala penilaian dengan menggunakan Tabel 4 berikut. TABEL 4

SKALA PENILAIAN PERBANDINGAN BERPASANGAN

\begin{tabular}{cc}
\hline Skala & Keterangan \\
\hline 1 & Kedua elemen sama pentingnya \\
3 & Elemen yang satu sedikit lebih penting daripada elemen yang \\
& lainnya \\
5 & Elemen yang satu lebih penting daripada yang lainnya \\
7 & Satu elemen jelas lebih mutlak penting daripada elemen \\
9 & lainnya \\
$2,4,6,8$ & Satu elemen mutlak penting daripada elemen lainnya \\
& bilai-nilai antara dua nilai pertimbangan-pertimbangan yang \\
berdekatan
\end{tabular}

Setelah didapatkan tabel matriks perbandingan berpasangannya, maka selanjutnya adalah menentukan bobot dari masing-masing kriteria dengan cara sebagai berikut :

Bobot kriteria $1=\frac{(1: A 4)+(B 1: B 4)+(C 1: C 4)+(D 1: D 4)}{J u m l a h \text { kriteria }(n=4)}$
Bobot kriteria $2=\frac{(1 / B 1: A 4)+(1: B 4)+(C 2: C 4)+(D 2: D 4)}{4}$
Bobot kriteria $3=\frac{(1 / C 1: A 4)+(1 / C 2: B 4)+(1: C 4)+(D 3: D 4)}{4}$
Bobot kriteria $4=\frac{(1 / D 1: A 4)+(1 / D 2: B 4)+(1 / D 3: C 4)+(1: D 4)}{4}$

Bobot masing-masing kriteria tersebut haruslah diuji terlebih dahulu konsistensinya. Pertama dihitung dahulu Principal Eigen Value $(\lambda \max )$ nya dengan rumus :

$\lambda \max =($ A4xBobot kriteria 1$)+(B 4 x$ Bobot kriteria 2$)+$ $($ C $4 x$ Bobot kriteria 3$)+(D 4 x$ Bobot kriteria 4$)$

Setelah dihitung $\lambda \max$ nya maka berikutnya adalah menghitung Consistency Index (CI) dengan rumus :

$$
\mathrm{CI}=\frac{\lambda \max -(\text { jumla } \square \text { kriteria } n)}{(\text { jumlah kriteria } n)-1}
$$

Setelah didapatkan Nilai CI maka berikutnya adalah menghitung nilai Random Consistency Index (CR) dengan cara membandingkan dengan Tabel 5.

$$
\begin{array}{cccccc} 
& & \multicolumn{3}{c}{\text { TABEL 5 }} \\
& & & \multicolumn{3}{c}{\text { TABEL RI }} \\
\hline \mathrm{N} & 1 & 2 & 3 & 4 & 5 \\
\hline \mathrm{RI} & 0,00 & 0,00 & 0,58 & 0,9 & 1, \\
\hline \mathrm{CR}=\frac{\mathrm{CI}}{R I} & & & & \\
& & & &
\end{array}
$$

\begin{tabular}{ccccccccc}
\multicolumn{10}{c}{ TABEL RI } \\
\hline $\mathrm{N}$ & 1 & 2 & 3 & 4 & 5 & 6 & 7 & 8 \\
\hline $\mathrm{RI}$ & 0,00 & 0,00 & 0,58 & 0,9 & 1,12 & 1,24 & 1,32 & 1,41 \\
\hline
\end{tabular}

Nilai RI untuk kriteria sebanyak empat adalah $=$ 0,9 maka, $\mathrm{CR}=\mathrm{CI} / 4$. Pembobotan dinilai konsisten apabila hasil $\mathrm{CR}<0,1$.

Indikator-indikator utama penyusun tabel KPI yang kelak digunakan sebagai tolok ukur kinerja perusahaan antara lain:
1. Perspektif keuangan
a. Persentase kenaikan/penurunan revenue
b. Operating ratio
c. Total debt to total asset
d. Current ratio

2. Perspektif pelanggan
a. Persentase ontime delivery
b. Persentase penyelesaian keluhan pelanggan

3. Perspektif proses bisnis internal
a. Persentase terjadinya salah entry service type
b. Outstanding invoice yang tersisa
c. Outstanding shipment yang tersisa
d. Pembayaran agent dan vendor

4. Perspektif pembelajaran dan pertumbuhan
a. Persentase karyawan keluar dari perusahaan
b. Penyelenggaraan acara sosialisasi MVVM
c. Jumlah pelatihan dan pengembangan skill karyawan
d. Pembayaran gaji karyawan

\section{HASIL DAN PEMBAHASAN}

\section{A. Hasil Pengukuran Kinerja dengan Metode Saat ini}

Berikut adalah hasil pengukuran kinerja dengan menggunakan metode yang digunakan pada saat ini.

1. Data revenue dari Departemen Accounting.

Data ini diamati kenaikan/penurunan dibandingkan tahun-tahun sebelumnya. Jika trendingnya naik berarti kinerja perusahaan secara keseluruhannya baik, dan begitu pula sebaliknya. Jika trendingnya turun berarti kinerjanya buruk. Pada penelitian ini data yang diamati adalah data tahun

\begin{tabular}{|c|c|c|c|}
\hline No & Income Statement & December 2012 & December 2013 \\
\hline 1 & Express Airfreight & 21.417 .296 .504 & 12.035 .038 .544 \\
\hline 2 & Document Domestic & 2.018 .853 .570 & 2.529 .284 .396 \\
\hline 3 & Surface Cargo & 24.488 .963 .870 & 22.322 .640 .176 \\
\hline 4 & City Courier Document & 4.290 .193 .370 & 1.499 .169 .250 \\
\hline 5 & City Courier Cargo & 834.478 .363 & 1.093.088.157 \\
\hline 6 & $\begin{array}{l}\text { Trucking Pickup, } \\
\text { contractual, }\end{array}$ & 4.448.430.514 & 3.452.242.339 \\
\hline 7 & Manpower dedicated & 133.650 .971 & 203.887 .580 \\
\hline 8 & Rider Motorcyle Dedicated & 6.991 .266 .884 & 7.399 .025 .985 \\
\hline 9 & Cargo Motorcycle Small & 75.726 .001 & 30.559 .398 \\
\hline 10 & Storage only & & 761.303 .457 \\
\hline 11 & Customs Clearance & & 228.025 .400 \\
\hline 12 & Sales Credit DHL (CAP) & 11.078.202 & 19.667 .000 \\
\hline 13 & $\begin{array}{l}\text { Discount } \\
\text { Revenue (Nett) }\end{array}$ & $\begin{array}{r}-\quad 80.785 .028 \\
64.629 .153 .221\end{array}$ & $\begin{array}{c}159.457 .541 \\
51.414 .474 .141\end{array}$ \\
\hline
\end{tabular}
2012 dan 2013, yang bisa dilihat pada Tabel 6 .

TABEL 6

DATA REVENUE PT. CY (DALAM RUPIAH)

2. Data Shipment Volume dari Departemen Operations.

Data ini diamati kenaikan/penurunan dibandingkan tahun-tahun sebelumnya. Jika trendingnya naik berarti kinerjanya baik, dan begitu pula sebaliknya.

TABEL VII

DATA SHIPMENT VOLUME PT. CY (DALAM KG) Service Type 2012 2013 


\begin{tabular}{ccc}
\hline Air Freight Domestic & 1.329 .863 & 845.542 \\
City Courier Cargo & 319.108 & 384.431 \\
City Courier Document & 192.758 & 140.795 \\
Custom Clearance & - & 6.281 \\
Dedicated Man Power & 22 & 55 \\
Dedicated Rider Motorcycle & 2.425 & 2.451 \\
Document Domestic & 151.702 & 112.173 \\
Handcarry City Courier & 6 & - \\
Handcarry Domestic & 2 & - \\
LCT Charter & 281.732 & - \\
Suface Cargo & 10.252 .051 & 8.346 .737 \\
Trucking & 6.001 .240 & 5.298 .330 \\
Warehouse & 218 & 944 \\
Grand Total & 18.533 .140 & 15.139 .752 \\
\hline
\end{tabular}

3. Data Outstanding Shipment dari Departemen Operations.

Data ini diamati jumlah outstanding shipment nya dibandingkan tahun-tahun sebelumnya. Jika jumlahnya turun bahkan sampai nol sama sekali berarti kinerjanya baik, dan begitu pula sebaliknya.

TABEL 8

\begin{tabular}{|c|c|c|}
\hline Under & 2012 & 2013 \\
\hline Balikpapan & 5 & - \\
\hline Bandung & 4 & - \\
\hline Batam & 1 & 5 \\
\hline Bengkulu & 4 & 5 \\
\hline Bekasi & - & 4 \\
\hline Berau & 15 & - \\
\hline Bontang & 10 & - \\
\hline Cilegon & 1 & - \\
\hline Denpasar & 6 & - \\
\hline Jakarta Husein & 2 & 6 \\
\hline Jakarta Nangka & 4 & 11 \\
\hline Jambi & 2 & 6 \\
\hline Jember & 2 & - \\
\hline Kudus & 2 & - \\
\hline Malang & 5 & - \\
\hline Manado & 4 & 1 \\
\hline Padang & 16 & 6 \\
\hline Palembang & 4 & 1 \\
\hline Pangkal Pinang & 2 & 8 \\
\hline Pekanbaru & 16 & - \\
\hline Pontianak & 7 & 4 \\
\hline Samarinda & 3 & - \\
\hline Sampit & 8 & - \\
\hline Sangatta & 1 & - \\
\hline Semarang & 1 & - \\
\hline Surabaya & 6 & - \\
\hline Tanjung Karang & 1 & - \\
\hline Tarakan & 11 & - \\
\hline Ujung Pandang & 19 & 40 \\
\hline Yogyakarta & 5 & 12 \\
\hline Grand Total & 167 & 109 \\
\hline
\end{tabular}

4. Data Outstanding Invoice dari Departemen Billing and Collection.

Data ini diamati jumlah outstanding shipment nya dibandingkan tahun-tahun sebelumnya. Jika jumlahnya turun bahkan sampai nol sama sekali berarti kinerjanya baik, dan begitu pula sebaliknya.

TABEL 9

DATA OUTSTANDING INVOICE PT CY (DALAM JUMLAH CN)

\begin{tabular}{ccc} 
DATA OUTSTANDING INVOICE PT. CY (DALAM JUMLAH CN) \\
\hline BulanKe- & 2012 & 2013 \\
\hline 1 & - & 15 \\
2 & 1 & 9 \\
3 & 1 & 8 \\
4 & 2 & 16 \\
5 & 16 & 16 \\
\hline
\end{tabular}

\begin{tabular}{ccc}
\hline 6 & 19 & 12 \\
7 & 18 & 39 \\
8 & 24 & 8 \\
9 & 21 & 18 \\
10 & 30 & 18 \\
11 & 23 & 52 \\
12 & 21 & 38 \\
Total & 176 & 249 \\
\hline
\end{tabular}

B. Hasil Pengukuran Kinerja dengan Metode Balanced Scorecard

Perancangan sistem Balanced Scorecard pada PT. CY diawali dengan menganalisis perusahaan dengan menggunakan Five-Forces Competitive Model. Hasilnya dapat dilihat pada Gambar 2.

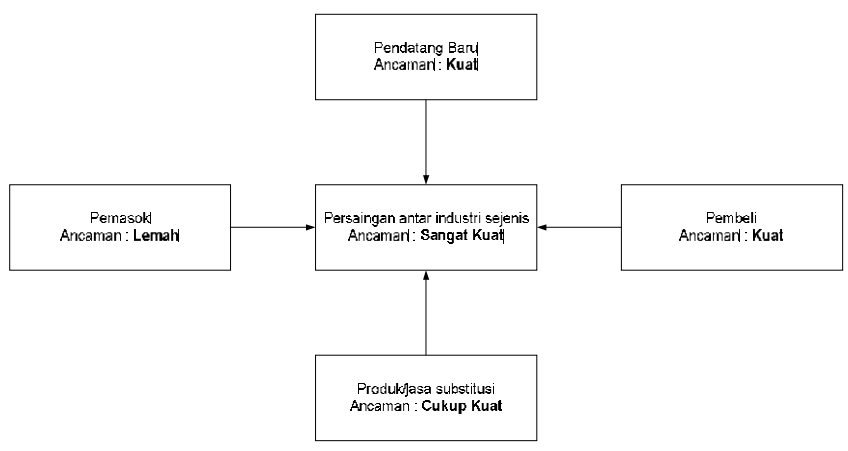

Gambar 2. Porter's Five-Forces Competitive Model PT. CY

Setelah itu ditentukan sasaran-sasaran strategis perusahaan untuk pembuatan peta strategi (strategy map). Kemudian sasaran-sasaran strategi tersebut bersama-sama dengan keempat perspektif Balanced Scorecard diberikan pembobotan disertai dengan tolok ukurnya untuk pembuatan tabel KPI.

Penyusunan sasaran-sasaran strategis untuk melengkapi empat perspektif Balanced Scorecard dilakukan dengan cara wawancara dan brainstorming dengan para supervisor, manajer dan manajer senior yang merupakan perwakilan dari masing-masing departemen dalam perusahaan. Berikut adalah sasaran-sasaran strategis yang berhasil dirumuskan:

1. Perspektif keuangan:

a. Peningkatan pendapatan perusahaan

b. Efisiensi perusahaan

c. Perbaikan resiko keuangan perusahaan

d. Perbaikan pembayaran hutang perusahaan

2. Perspektif pelanggan:
a. Peningkatan kepuasan pelanggan

b. Kualitas layanan yang baik

3. Perspektif proses bisnis internal:
a. Minimasi kesalahan kegiatan operasi perusahan
b. Percepatan pembuatan invoice
c. Minimasi outstanding shipment
d. Percepatan pembayaran operasional

4. Perspektif pembelajaran dan pertumbuhan:
a. Mempertahankan karyawan
b. Sosialisasi visi, misi dan strategi perusahaan
c. Pelatihan dan pengembangan skill karyawan
d. Perhatian kesejahteraan karyawan 
Sasaran-sasaran strategis tersebut kemudian dijabarkan indikator-indikator yang kelak menjadi tolok ukur dalam pembuatan KPI. Indikator-indikator tersebut diseleksi dilakukan dengan metode USG. Setelah dilakukan penentuan prioritas dari indikatorindikator tersebut, maka kemudian dipilihlah empat indikator dengan skor terbesar untuk dijadikan indikator utama dalam pembuatan tabel KPI. Hasilnya bisa dilihat pada tabel-tabel berikut.

TABEL 10

PENENTUAN PRIORITAS INDIKATOR-INDIKATOR PERSPEKTIF KEUANGAN

\begin{tabular}{|c|c|c|c|c|c|}
\hline Sasaran Strategi & Indikator & $\mathrm{U}$ & $\mathrm{S}$ & G & Total \\
\hline $\begin{array}{c}\text { Peningkatan } \\
\text { pendapatan perusahaan }\end{array}$ & $\begin{array}{c}\text { Persentase } \\
\text { kenaikan/penurunan } \\
\text { revenue }\end{array}$ & 5 & 4 & 5 & 14 \\
\hline \multirow{2}{*}{ Efisiensi perusahaan } & Operating Ratio & 4 & 5 & 3 & 12 \\
\hline & Net Margin Ratio & 3 & 3 & 3 & 9 \\
\hline \multirow{2}{*}{$\begin{array}{c}\text { Perbaikan resiko } \\
\text { keuangan perusahaan }\end{array}$} & $\begin{array}{l}\text { Total Debt to Total } \\
\text { Asset Ratio }\end{array}$ & 4 & 3 & 4 & 11 \\
\hline & $\begin{array}{c}\text { Ratio of Owner's } \\
\text { Equity to Total } \\
\text { Assets }\end{array}$ & 3 & 2 & 2 & 7 \\
\hline \multirow{2}{*}{$\begin{array}{l}\text { Perbaikan pembayaran } \\
\text { hutang perusahaan }\end{array}$} & Current Ratio & 5 & 5 & 5 & 15 \\
\hline & Acid Test Ratio & 3 & 3 & 3 & 9 \\
\hline
\end{tabular}

TABEL 11

PENENTUAN PRIORITAS INDIKATOR-INDIKATOR PERSPEKTIF PELANGGAN

\begin{tabular}{cccccc}
\hline Sasaran Strategi & Indikator & $\mathrm{U}$ & $\mathrm{S}$ & $\mathrm{G}$ & Total \\
\hline $\begin{array}{c}\text { Peningkatan kepuasan } \\
\text { pelanggan }\end{array}$ & $\begin{array}{c}\text { Persentase ontime } \\
\text { delivery } \\
\text { Persentase }\end{array}$ & 5 & 5 & 5 & $\mathbf{1 5}$ \\
$\begin{array}{c}\text { Kualitas layanan yang } \\
\text { baik }\end{array}$ & $\begin{array}{c}\text { penyelesaian klaim } \\
\text { pelanggan }\end{array}$ & 5 & 5 & 5 & $\mathbf{1 5}$
\end{tabular}

TABEL 12

PENENTUAN PRIORITAS INDIKATOR-INDIKATOR PERSPEKTIF PROSES BISNIS INTERNAL

\begin{tabular}{|c|c|c|c|c|c|}
\hline Sasaran Strategi & Indikator & $\mathrm{U}$ & $\mathrm{S}$ & G & Total \\
\hline \multirow{4}{*}{$\begin{array}{l}\text { Minimasi kesalahan } \\
\text { kegiatan operasi }\end{array}$} & $\begin{array}{l}\text { Terjadinya kasus } \\
\text { harga yang belum } \\
\text { diinput }\end{array}$ & 5 & 4 & 4 & 13 \\
\hline & Terjadinya kasus & & & & \\
\hline & $\begin{array}{l}\text { missed entry status } \\
\text { Terjadinya kasus } \\
\text { salah entry service }\end{array}$ & 4 & 4 & 3 & 11 \\
\hline & type & 5 & 5 & 5 & 15 \\
\hline \multirow{2}{*}{$\begin{array}{l}\text { Percepatan pembuatan } \\
\text { invoice }\end{array}$} & Outstanding Invoice & & & & \\
\hline & $\begin{array}{l}\text { yang tersisa } \\
\text { Outstanding }\end{array}$ & 5 & 5 & 5 & 15 \\
\hline $\begin{array}{l}\text { Minimasi outstanding } \\
\text { shipment }\end{array}$ & $\begin{array}{l}\text { Shipment yang } \\
\text { tersisa }\end{array}$ & 5 & 5 & 5 & 15 \\
\hline \multirow[t]{2}{*}{ Percepatan pembayaran } & $\begin{array}{l}\text { Pembayaran petty } \\
\text { cash cabang }\end{array}$ & 4 & 4 & 4 & 12 \\
\hline & $\begin{array}{l}\text { Pembayaran agent } \\
\text { dan vendor }\end{array}$ & 5 & 4 & 5 & 14 \\
\hline
\end{tabular}

TABEL 13

PENENTUAN PRIORITAS INDIKATOR-INDIKATOR PERSPEKTIF PEMBELAJARAN DAN PERTUMBUHAN

\begin{tabular}{|c|c|c|c|c|c|}
\hline Sasaran Strategi & Indikator & $\mathrm{U}$ & $\mathrm{S}$ & $\mathrm{G}$ & Total \\
\hline \multirow{2}{*}{$\begin{array}{l}\text { Mempertahankan } \\
\text { pekerja }\end{array}$} & Karyawan masuk & 4 & 4 & 3 & 11 \\
\hline & Karyawan keluar & 4 & 4 & 5 & 13 \\
\hline $\begin{array}{l}\text { Sosialisasi visi, misi } \\
\text { dan strategi perusahaan }\end{array}$ & $\begin{array}{l}\text { Penyelenggaraan } \\
\text { acara MVVM }\end{array}$ & 4 & 4 & 4 & 12 \\
\hline $\begin{array}{c}\text { Pelatihan dan } \\
\text { pengembahan skill } \\
\text { karyawan }\end{array}$ & $\begin{array}{c}\text { Pelatihan yang } \\
\text { diadakan } \\
\text { perusahaan }\end{array}$ & 5 & 5 & 4 & 14 \\
\hline
\end{tabular}

\begin{tabular}{|c|c|c|c|c|c|}
\hline \multirow{3}{*}{$\begin{array}{c}\text { Perhatian kesejahteraan } \\
\text { karyawan }\end{array}$} & $\begin{array}{c}\text { Payment gaji } \\
\text { karyawan }\end{array}$ & 5 & 5 & 5 & 15 \\
\hline & Payment claim & 3 & 4 & 4 & 11 \\
\hline & $\begin{array}{c}\text { kesehatan karyawan } \\
\text { Payment lemburan } \\
\text { karyawan }\end{array}$ & 3 & 4 & 4 & 11 \\
\hline
\end{tabular}

Berikut adalah gambar dari peta strategi perusahaan disusun dari sekumpulan sasaran-sasaran strategi dari masing-masing perspektif dalam Balanced Scorecard hasil proses sebelumnya.

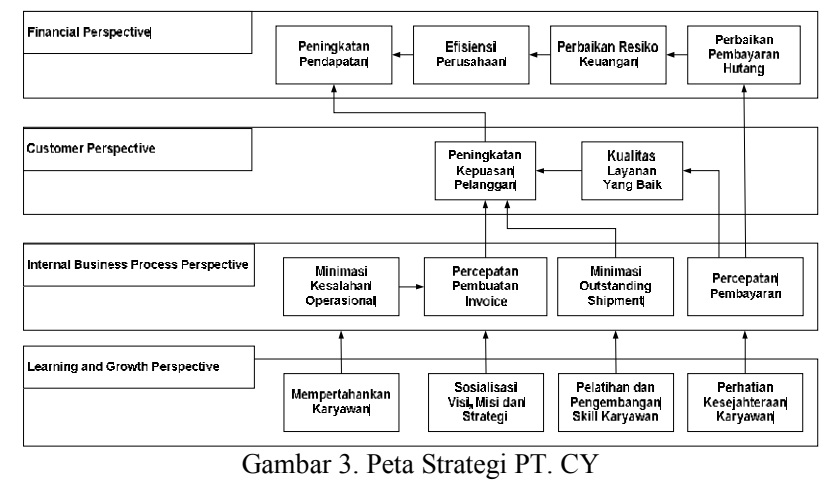

Indikator-indikator dari masing-masing perspektif dihitung bobotnya dengan menggunakan metode AHP. Hasilnya adalah seperti tampak pada tabel-tabel berikut.

TABEL 14

PEMBOBOTAN INDIKATOR-INDIKATOR PERSPEKTIF KEUANGAN

\begin{tabular}{cc} 
PERSPEKTIF KEUANGAN & \\
\hline Kriteria & Bobot \\
\hline Persentase kenaikan/penurunan revenue & 0.263 \\
Operating Ratio & 0.122 \\
Total Debt to Total Asset Ratio & 0.057 \\
Current Ratio & 0.558 \\
Jumlah & 1 \\
\hline
\end{tabular}

TABEL 15

PEMBOBOTAN INDIKATOR-INDIKATOR PERSPEKTIF PELANGGAN

\begin{tabular}{cc}
\hline Kriteria & Bobot \\
\hline Ontime delivery & 0.833 \\
Penyelesaian klaim pelanggan & 0.167 \\
Jumlah & 1 \\
\hline
\end{tabular}

TABEL 16

PEMBOBOTAN INDIKATOR-INDIKATOR PERSPEKTIF BISNIS PROSES INTERNAL

\begin{tabular}{cc}
\hline Kriteria & Bobot \\
\hline Terjadinya kasus salah entry service type & 0.429 \\
Outstanding Invoice yang tersisa & 0.304 \\
Outstanding Shipment yang tersisa & 0.206 \\
Payment agent dan vendor & 0.061 \\
Jumlah & 1 \\
\hline
\end{tabular}

TABEL 17

PEMBOBOTAN INDIKATOR-INDIKATOR PERSPEKTIF PEMBELAJARAN DAN PERTUMBUHAN

\begin{tabular}{cc}
\hline Kriteria & Bobot \\
\hline Karyawan keluar & 0.050 \\
Penyelenggaraan acara MVVM & 0.105 \\
Pelatihan yang diadakan perusahaan & 0.243 \\
Payment gaji karyawan & 0.602 \\
Jumlah & 1 \\
\hline
\end{tabular}


Setelah indikator-indikator dari masing-masing perspektif dihitung bobotnya, maka selanjutnya adalah mengalikan bobot-bobot indikator tersebut dengan bobot perspektifnya. Sehingga hasilnya tampak seperti pada Tabel 14.

TABEL 18

PEMBOBOTAN UNTUK SEMUA INDIKATOR

\begin{tabular}{ccc}
\hline Perspektif & Kriteria & $\%$ \\
\hline \multirow{3}{*}{ Keuangan } & Persentase kenaikan/penurunan & $11,35 \%$ \\
& revenue & $5,25 \%$ \\
& Operating Ratio & $2,45 \%$ \\
Total Debt to Total Asset Ratio & Current Ratio & $24,05 \%$ \\
Pelanggan & Ontime delivery & $3,97 \%$ \\
& Persentase penyelesaian klaim & $0,79 \%$ \\
& pelanggan & \\
Bisnis Proses & Terjadinya kasus salah entry serı & $6,21 \%$ \\
Internal & type & \\
& Outstanding Invoice yang & $4,40 \%$ \\
& tersisa & $2,97 \%$ \\
& Outstanding Shipment yang & tersisa \\
Pembelajaran dan & Penyelenggaraan acara MVVM & $3,94 \%$ \\
Pertumbuhan & Pelatihan yang diadakan & $9,16 \%$ \\
& perusahaan & $22,69 \%$ \\
Total & Payment gaji karyawan & $100,00 \%$ \\
\hline
\end{tabular}

Sistem pengukuran kinerja perusahaan yang dilakukan PT. CY pada saat ini sangatlah tidak memadai dan tidak bisa menggambarkan kinerja perusahaan secara komprehensif. Dalam [2] telah dijelaskan bahwa Balanced Scorecard menyediakan para manajer suatu instrumen yang dibutuhkan untuk mengemudikan perusahaan menuju kepada keberhasilan persaingan masa depan. Balanced Scorecard lebih dari sekedar sistem pengukuran taktis atau operasional. Perusahaan yang inovatif menggunakan Scorecard sebagai sebuah sistem manajemen strategis untuk mengelola strategi jangka panjang. Perusahaan menggunakan fokus pengukuran Scorecard untuk menghasilkan berbagai proses manajemen penting :

1. Memperjelas dan menerjemahkan visi dan strategi

2. Mengkomunikasikan dan mengaitkan berbagai tujuan dan ukuran strategis

3. Merencanakan, menetapkan sasaran dan menyelaraskan berbagai inisiatif strategis

4. Meningkatkan umpan balik dan pembelajaran strategis

Hasil perhitungan KPI dengan metode Balanced Scorecard pada penelitian ini memiliki skor yang rendah, artinya kinerja perusahaan secara keseluruhan adalah buruk. Faktor utama penurunan kinerja perusahaan yang terjadi di PT. CY pada saat ini adalah lebih disebabkan oleh kondisi keuangan perusahaan yang buruk.

TABEL XIX

HASIL PERHITUNGAN TABEL KPI

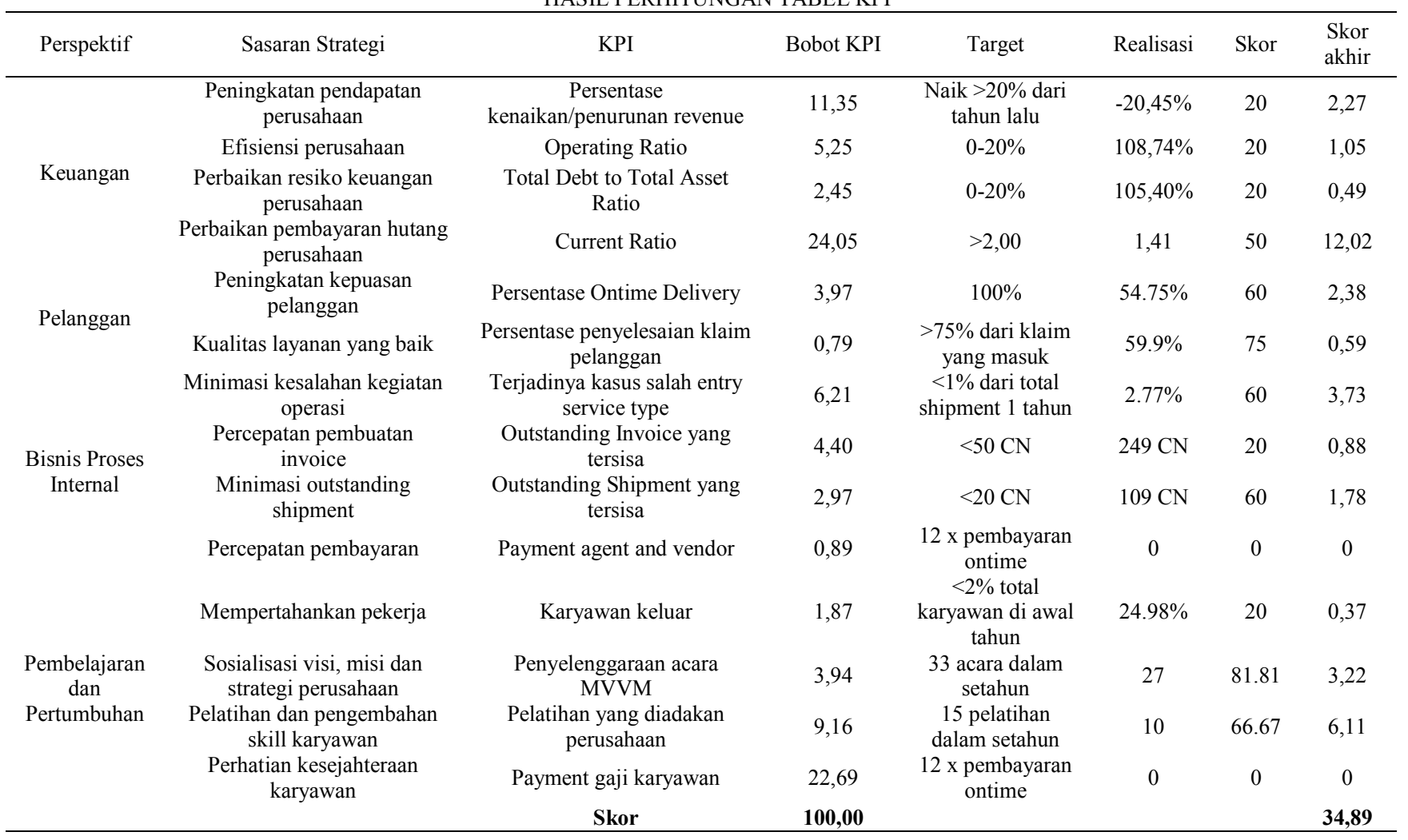


Kondisi ini pada akhirnya menyebabkan perhatian perusahaan kepada para karyawannya tidak diperhatikan. Perusahaan belum bisa memperhatikan secara baik terutama masalah hak-hak dan kesejahteraan para karyawannya, padahal penerapan Balanced Scorecard haruslah melibatkan seluruh karyawan di berbagai level agar strategi perusahaan bisa berjalan secara optimal. Kondisi perusahaan yang tidak sehat menyebabkan kinerja perusahaan ditinjau dari empat perspektif Balanced Scorecard buruk, hal ini ditunjukkan dengan rendahnya skorskor yang ada pada tabel KPI untuk sebagian besar indikator.

Meski kondisi keuangan perusahaan sedang tidak sehat, namun ada dua indikator yang memiliki skor yang besar di atas 70 yakni indikator "penyelesaian klaim pelanggan" dan "penyelenggaraan acara MVVM". Besarnya skor indikator pertama artinya perusahaan masih mau bertanggung jawab terhadap keluhan pelanggan demi tercapainya kepuasan mereka. Hal sesuai dengan nilai luhur yang dianut oleh PT. CY. Besarnya skor indikator kedua artinya perusahaan masih giat untuk mensosialisasikan visi, misi dan strategi mereka kepada para karyawannya. Penyelenggaraan acara MVVM adalah salah satu momen untuk menyemangati karyawannya dan menjadi sarana komunikasi antara top level management dengan middle and low level menagement.

Tabel KPI yang sudah dibuat juga menunjukkan sasaran-sasaran strategis yang memiliki bobot KPI besar di atas 10\% lebih menekankan kepada strategi untuk meningkatkan pendapatan perusahaan, perbaikan pembayaran hutang perusahaan dan pembayaran gaji karyawan yang tepat waktu. Kelak, jika sasaran-sasaran strategis ini bisa tercapai maka akan berpengaruh secara signifikan terhadap peningkatan kinerja perusahaan secara keseluruhan. Namun, faktanya saat ini perusahaan masih belum mampu untuk melakukan pembayaran gaji karyawan secara tepat waktu, hal ini bisa dilihat dari skor 0 untuk indikator "pembayaran gaji karyawan", padahal bobot KPI untuk indikator tersebut sangat signifikan.

Skor akhir tertinggi dimiliki oleh indikator "current ratio" hal ini dapat dikatakan bahwa PT. CY sedang menyiasati untuk memperbaiki hutanghutangnya. Namun, hal ini tidak akan berarti banyak karena indikator tersebut hanyalah sebagian kecil dari kumpulan-kumpulan indikator yang lain penyusun tabel KPI. Secara jelas dalam [2] dijelaskan bahwa Balanced Scorecard menekankan bahwa semua ukuran keuangan dan nonkeuangan harus menjadi bagian sistem informasi untuk para karyawan di semua tingkat perusahaan. Para karyawan lini depan harus memahami konsekuensi keuangan berbagai keputusan dan tindakan mereka. Para ekskutif senior harus memahami faktor yang mendorong keberhasilan keuangan jangka panjang. Tujuan dan ukuran dalam Balanced Scorecard lebih dari sekedar kumpulan ukuran kinerja keuangan dan nonkeuangan khusus. Semua tujuan dan ukuran ini diturunkan dari suatu proses atas ke bawah (top down) yang digerakkan oleh misi dan strategi unit bisnis.

\section{KESIMPULAN}

Balanced Scorecard sangat berguna bagi perusahaan ekspedisi umumnya dan PT. CY pada khususnya. Jika dibandingkan dengan pengukuran kinerja yang dimiliki perusahaan saat ini, maka dengan perancangan Balanced Scorecard bisa diketahui ada banyak kekurangan dari pengukuran kinerja yang dimiliki PT. CY tersebut. Selain lemah karena hanya menggunakan sedikit perspektif saja, penerapan Balanced Scorecard di PT. CY juga membuat perusahaan tersebut jadi memiliki sebuah metode pengukuran kinerja perusahaan yang lebih baik dari sebelumnya. Sebuah metode pengukuran yang komprehensif karena diambil dari empat perspektif yang jika keempatnya digabungkan maka akan menjadi representasi seluruh tubuh organisasi. Balanced Scorecard dalam [7] dijelaskan juga bisa menjadi alat manajemen strategis yang penting karena bisa diadopsi atau pun modifikasi untuk mencapai tujuan jangka panjang perusahaan.

Perancangan BalancedScorecard di PT. CY juga menghasilkan sebuah peta strategi dan tabel KPI yang penting untuk menyadarkan seluruh komponen karyawan dari level atas hingga bawah bahwa peran serta mereka mempengaruhi kinerja perusahaan secara keseluruhan. Dengan adanya tabel KPI maka strategi perusahaan lebih terukur dan semua karyawan bisa melihat bahwa strategi yang dijalankan apakah sesuai dengan visi dan misi yang diusung oleh perusahaan untuk tetap berkompetisi pada masa kini dan masa yang akan datang.

Perancangan Balanced Scorecard pada penelitian ini dibuat pada saat kondisi perusahaan berada pada kondisi keuangan yang tidak baik, penelitian selanjutnya hendaknya dilakukan pada saat kondisi perusahaan sudah mulai stabil sehingga rancangan Balanced Scorecard yang sudah ada bisa dimodifikasi disesuaikan dengan sasaran-sasaran strategis dan indikator-indikator yang baru agar menjadi alat pemicu kinerja perusahaan yang lebih baik lagi selain itu juga menjadi alat bagi PT. CY untuk mendapatkan keunggulan kompetitif di tengah persaingan industri ekspedisi yang demikian sengit.

Penelitian ini baru terbatas pada kantor pusat PT. CY saja, penelitian selanjutnya diharapkan bisa melibatkan permasalahan yang terjadi di kantorkantor cabang. Permasalahan di cabang bisa jadi berbeda dengan permasalahan yang terjadi di kantor 
pusat, tentunya harus didukung dengan data yang memadai disesuaikan dengan empat perspektif Balanced Scorecard.

\section{UCAPAN TERIMA KASIH}

Penulis ingin mengucapkan terima kasih kepada Kaprodi Teknik Industri Unindra, Ibu Elfitria Wiratmani, pak Ridwan Usman selaku Sekprodi Teknik Industri, rekan-rekan Tim Borang Reakreditasi Teknik Industri Unindra, serta istri tercinta Nurul Faiza yang tak pernah berhenti memberikan dukungan kepada penulis untuk terus belajar dan berkembang menjadi orang yang lebih baik lagi.

\section{REFERENCES}

[1] G. Giannopoulos, A. Holt, E. Khansalar, and S. Cleanthous, "The Use of the Balanced Scorecard in Small Companies," International Journal of Business and Management, vol.8, no.14, 2013.
[2] R. S. Kaplan, and D. P. Norton, "Balanced Scorecard: Menerapkan Strategi Menjadi Aksi," Penerbit Erlangga, Jakarta, 1996, pp. 9-36

[3] N. Kusuma, "Perancangan Balanced Scorecard Berbasis Analisis SOAR Pada Media Pertelevisian," S.T. Skripsi, Program Studi Teknik Industri, Fakultas Teknik, Institut Teknologi Sepuluh November,

[4] Subekty, "Perancangan Balanced Scorecard Induk Koperasi ABC," M.M. Thesis, Program Studi Magister Manajemen, Fakultas Ekonomi, Univ. Indonesia, Depok, Indonesia, 2011.

[5] H. Asmoko. (2010). Teknik Analisis Permasalahan Menentukan Masalah Prioritas. Pusdiklat Pengembangan SDM. BPPK. Magelang. [Online] Available : https://docplayer.info/29562830-Teknikanalisis-permasalahan-menentukan-masalahprioritas.html

[6] T. L. Saaty, "Multicriteria Decision Making : The Analytic Hierarchy Process," University of Pittsburgh, RWS Publication, Pittsburgh, pp.23-37, 1988.

[7] A. Sharma, "Implementing Balanced Scorecard for Performance Measurement," The Icfai Business School. Jaipur, India. The IUP Journal of Business Strategy. Vol.6, no.1, pp.7-16, 2009. 